\title{
Intracrystalline melt migration in deformed olivine revealed by trace element compositions and polyphase solid inclusions
}

\author{
Valentin Basch ${ }^{1,2}$, Martyn R. Drury ${ }^{3}$, Oliver Plumper ${ }^{3}$, Eric Hellebrand ${ }^{3}$, Laura Crispini ${ }^{1}$, \\ Fabrice Barou ${ }^{4}$, Marguerite Godard ${ }^{4}$, and Elisabetta Rampone ${ }^{1}$ \\ ${ }^{1}$ Dipartimento di Scienze della Terra, dell'Ambiente e della Vita, University of Genova, \\ Corso Europa 26, Genova, Italy \\ ${ }^{2}$ Dipartimento di Scienze della Terra e dell'Ambiente, University of Pavia, Adolfo Ferrata 1, Pavia, Italy \\ ${ }^{3}$ Faculty of Geoscience, Utrecht University, Princetonlaan 8, Utrecht, the Netherlands \\ ${ }^{4}$ Géosciences Montpellier, CNRS, University of Montpellier, Montpellier, France
}

Correspondence: Valentin Basch (valentin.basch@gmail.com)

Received: 4 May 2021 - Revised: 6 July 2021 - Accepted: 14 July 2021 - Published: 12 August 2021

\begin{abstract}
Melt transport mechanisms have an important impact on the chemical composition of the percolated host rock and the migrating melts. Melt migration is usually assumed to occur at grain boundaries. However, microstructural studies revealed the occurrence of polyphase inclusions along dislocations, subgrain boundaries and microcracks in single mineral grains. The inclusions are interpreted as crystallized melt pockets suggesting that melts can migrate within deformed crystals. Intracrystalline melt migration and diffusive re-equilibration can lead to significant mineral trace element enrichments when associated with dissolution-precipitation reactions. In this contribution, we study a body of replacive troctolites associated with the Erro-Tobbio ophiolitic mantle peridotites (Ligurian Alps, Italy). The replacive formation of the olivine-rich troctolite involved extensive impregnation of a dunitic matrix, i.e. partial dissolution of olivine and concomitant crystallization of interstitial phases. The olivine matrix is characterized by two distinct olivine textures: (i) coarse deformed olivine, representing relicts of the pre-existing mantle dunite matrix (olivine ${ }_{1}$ ), and (ii) fine-grained undeformed olivine, a product of the melt-rock interaction process $\left(\right.$ olivine $\left._{2}\right)$. Previous studies documented a decoupling between olivine texture and trace element composition, namely enriched trace element compositions in olivine ${ }_{1}$ rather than in olivine 2 , as would be expected from the dissolution-precipitation process. Notably, the trace element enrichments in deformed olivines are correlated with the occurrence of elongated $10 \mu \mathrm{m}$ size polyphase inclusions (clinopyroxene, Ti-pargasite, chromite) preferentially oriented along olivine crystallographic axes. These inclusions show irregular contacts and have no crystallographic preferred orientation with the host olivine, and the phases composing the inclusions show similar chemical compositions to the vermicular phases formed at the grain boundaries during late-stage reactive crystallization of the troctolite. This suggests that the investigated inclusions did not form as exsolutions of the host olivine but rather by input of metasomatic fluids percolating through the deformed olivine grains during closure of the magmatic system. We infer that strongly fractionated volatile-rich melts were incorporated in oriented microfractures within olivine ${ }_{1}$ and led to the crystallization of the polyphase inclusions. The presence of intracrystalline melt greatly enhanced diffusive re-equilibration between the evolved melt and the percolated olivine ${ }_{1}$, in turn acquiring the enriched character expected in neoformed olivine crystals. Intracrystalline melt percolation can have strong geochemical implications and can lead to efficient re-equilibration of percolated minerals and rocks.
\end{abstract}




\section{Introduction}

Melt transport mechanisms have an important impact on the structure and composition of percolated host rocks and migrating melts. Melt migration is usually assumed to occur by diffuse percolation along grain boundaries or by focused migration in veins and dikes (e.g. Sparks and Parmentier, 1991; Kelemen et al., 1997). However, transmission electron microscope (TEM) studies revealed the occurrence of melt pockets along dislocations and subgrain boundary networks or microcracks in single mineral grains, suggesting that melts can migrate within deformed crystals (Drury and Van Roermund, 1989; De Kloe, 2001). Diffusion between crystals and melts is more efficient than solid-solid diffusion (e.g. Costa et al., 2008, 2020; Zhang and Cherniak, 2010). Intracrystalline melt transport is thus expected to affect chemical re-equilibration at the grain scale, leading to fast reequilibration between the percolated matrix and migrating melts (Drury and Van Roermund, 1989). In turn, diffusive reequilibration can lead to significant mineral trace element enrichments when associated with reactive melt transport (e.g. Sanfilippo et al., 2014; Rampone et al., 2016; Basch et al., 2018; Ferrando et al., 2020).

Recent studies demonstrated that melt-rock interactions and reactive porous flow are key processes in the global geochemical budget of the oceanic lithosphere and in the formation of the lower oceanic crust. During melt percolation within the mantle, reactive dissolution-precipitation processes between melt and mineral matrix can lead to significant chemical modification of migrating melts (Collier and Kelemen, 2010; Saper and Liang, 2014; Rampone et al., 2016; Basch et al., 2019a; Ferrando et al., 2021). Additionally, harzburgite-dunite mantle slivers can be incorporated at the base of the oceanic crust and transformed, by melt impregnation, into "hybrid" (i.e. mantle-derived) olivine-rich gabbroic rocks (Suhr et al., 2008; Drouin et al., 2009; Higgie and Tommasi, 2012; Sanfilippo et al., 2014; Basch et al., 2018, 2019b; Ferrando et al., 2018, 2020).

Reactive melt percolation has been extensively documented in oceanic environments characterized by a thick thermal lithosphere and thermal boundary layer, namely slow- and ultra-slow-spreading ridges. In these cold spreading environments, melts are produced at depth and need to percolate through a thick mantle column before reaching crystallization depths (e.g. Hebert and Montési, 2010; Sleep and Warren, 2014; Basch et al., 2019a, b; Rampone et al., 2020). These large-scale percolation processes enhance the reactivity of the melt towards the host mantle rock (e.g. Liang, 2003; Morgan and Liang, 2005) and lead to extensive impregnation of the mantle section (Sleep and Warren, 2014; Rampone et al., 2020). Accordingly, slow-spreading environments are ideal settings to study processes of melt migration and their implication in the composition of the oceanic lithosphere.
The Alpine-Apennine ophiolites are key analogues of lithosphere formed in ultra-slow-spreading ridges and hyperextended passive margin settings (e.g. Manatschal and Müntener, 2009; Rampone et al., 2014, 2020; Piccardo, 2016; Rampone and Sanfilippo, 2021). These ophiolites are predominantly constituted of mantle peridotites, which record various stages of melt-rock interaction that occurred at different mantle depths (e.g. Rampone and Borghini, 2008; Piccardo and Guarnieri, 2010; Basch et al., 2019a; Rampone et al., 2020).

In this contribution, we investigate the trace element compositions of olivine in olivine-rich troctolites primarily associated with the Erro-Tobbio ophiolitic mantle peridotites (Voltri Massif, Ligurian Alps, Italy; Fig. 1). Basch et al. (2019b) inferred that these olivine-rich troctolites have a multi-stage replacive origin, involving reactive percolation and interaction of MORB-type (mid-ocean ridge basalt) melt with mantle dunite. Within the replacive troctolite, the olivine matrix is characterized by two generations of olivine, namely (i) coarse deformed olivines (olivine ${ }_{1}$ ) and (ii) fine-grained undeformed olivines (olivine ${ }_{2}$ ). Rampone et al. (2016) documented a decoupling between olivine texture and its trace element composition, with substantial trace element enrichments in olivine ${ }_{1}$, representing relicts of the preexisting mantle dunite matrix. In this paper, we show that these trace element enrichments result from a process of intracrystalline melt migration within deformed olivine ${ }_{1}$ crystals, as evidenced by the occurrence of oriented polyphase solid inclusions.

\section{Geological setting and previous results}

The Erro-Tobbio ultramafic body pertains to the AlpineApennine ophiolites (Fig. 1; see Basch et al., 2019b). These ophiolites represent the lithospheric remnants of the narrow oceanic basin of the Jurassic Ligurian Tethys, which opened by passive extension and breakup of the Europe-Adria continental lithosphere, followed by slow-spreading oceanization (e.g. Manatschal and Müntener, 2009; Rampone et al., 2020).

The Erro-Tobbio peridotites preserve microstructures and geochemical compositions indicative of a composite meltrock interaction history related to the exhumation of this mantle section from spinel to plagioclase facies depths to shallow oceanic environments (Rampone et al., 2004, 2005, 2016, 2020; Borghini and Rampone, 2007; Borghini et al., 2007; Piccardo and Vissers, 2007; Rampone and Borghini, 2008; Basch et al., 2019b). The plagioclase-bearing impregnated mantle peridotites are primarily associated with a hectometre-size body of olivine-rich troctolites and crosscutting gabbroic dikes (Borghini et al., 2007; Borghini and Rampone, 2007; Rampone and Borghini, 2008; Rampone et al., 2016; Basch et al., 2019b), interpreted as early magmatic episodes within the thinned lithospheric mantle in ocean- 

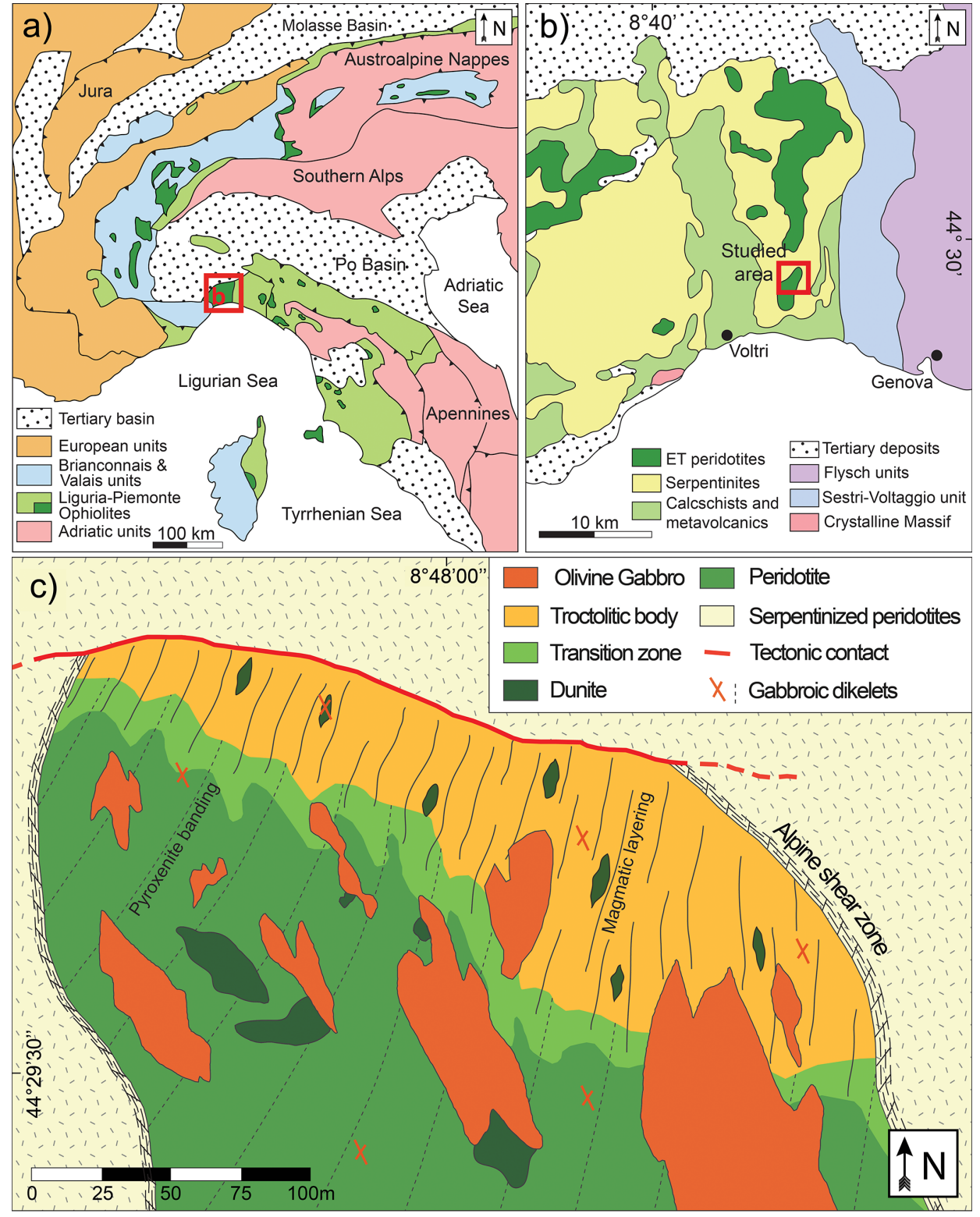

Figure 1. Tectonic and geological maps of the studied area, redrawn based on Basch et al. (2019b). (a) Sketch map of the northern Apennines and western Alps. The red square indicates the location of the Voltri Massif, in the Ligurian Alps. (b) Map of the Voltri Massif and location of the studied area within the Erro-Tobbio peridotites. (c) Geological map of the studied area.

continent transition settings (e.g. Manatschal and Müntener, 2009; Basch et al., 2019b).

Within the Erro-Tobbio troctolitic body, clear structural relationships provide a good field control on melt migration and intrusion processes (see Basch et al., 2019b). Namely, the troctolitic body is formed of a host troctolite (Troctolite A) crosscut by a second generation of troctolitic metre-size bodies (Troctolite B). The host troctolite has been interpreted to be of replacive origin, i.e. formed by melt-rock interaction processes during reactive melt percolation within the lithospheric mantle. Subsequent focused melt percolation and melt intrusions formed the
Troctolite B and gabbroic dikes, respectively (see Fig. 19 in Basch et al., 2019b). The replacive formation of the host Troctolite A involved the impregnation of a deformed dunitic matrix, i.e. partial dissolution of olivine and concomitant crystallization of interstitial plagioclase and clinopyroxene $\left(\mathrm{ol}_{1} \pm \mathrm{sp}_{1}+\right.$ melt $_{1}=\mathrm{ol}_{2}+\mathrm{pl}_{2} \pm \mathrm{cpx}_{2}+$ melt $\left._{2}\right)$. Partial dissolution of the pre-existing dunite was accompanied by extensive recrystallization of the olivine matrix. This is clearly evidenced by electron backscatter diffraction (EBSD) analyses indicating two generations of olivine in the replacive troctolite (Fig. 2a; Basch et al., 2019b), namely (i) coarse corroded deformed olivine, representing 
relicts of the pre-existing mantle dunite matrix (olivine ${ }_{1}$; Fig. 2a, b), and (ii) chadacrystic fine-grained euhedral undeformed olivine, a product of the melt-rock interaction process (olivine 2 ; Fig. 2a, c). Notably, the latter fine-grained olivine is not necessarily crystallized from the melt involved in the dissolution-precipitation process leading to the formation of the replacive Troctolite A; rather, they result from the dismembering of coarse-grained olivine ${ }_{1}$ during their partial dissolution (see Fig. 15 in Basch et al., 2019b, for more detail on the evolution of olivine textures and associated crystallographic preferred orientations during progressive melt-rock interaction).

In the Erro-Tobbio troctolitic body, the extensive dissolution-precipitation processes that formed the host troctolite led to the progressive modification of the residual melt composition, as modelled by Basch et al. (2019b) and Rampone et al. (2016) for major and trace element compositions, respectively. Rampone et al. (2016) modelled the impact of the reactive crystallization process on the melt composition and demonstrated that the replacive formation of the troctolite was associated with strong trace element enrichments in the residual melt. Remarkably, Rampone et al. (2016) reported an apparent decoupling between texture and trace element chemical signature of olivine, documenting enriched trace element compositions in the coarse-grained deformed olivines (olivine ${ }_{1}$ ) rather than in the fine-grained euhedral olivines (olivine 2 ). In this contribution, we aim to unravel the origin of the decoupling between olivine texture and trace element composition and assess its relationship to grain-scale melt migration processes.

\section{Studied samples and methodologies}

Because of the replacive character of the troctolites, the composition of the pre-existing matrix of mantle olivine ${ }_{1}$ has been partially re-equilibrated towards an equilibrium composition with the percolating melt; as a result, olivines forming the matrix show major element and compatible to moderately incompatible element compositions fitting intermediately between the compositions of olivine in the peridotites and gabbros (Rampone et al., 2016). Concomitantly, dissolutionprecipitation led to specific enrichments in highly incompatible trace elements in the residual melt and re-equilibrated minerals (see Rampone et al., 2016).

In order to compare the trace element enrichments in the olivine of Troctolites A with the compositions of precursor mantle crystals and magmatic olivine in gabbros, we included in this work the trace element compositions of olivines in spinel and plagioclase lherzolites, dunites, olivine-rich troctolites, and gabbroic dikes. The list of studied samples and the whole olivine trace element dataset are reported in Supplement Tables S1 and S2, respectively. Further information about the major and trace element mineral composition of studied samples are found in Rampone et al. (2016) and Basch et al. (2019b). Laser ablation inductively coupled plasma mass spectrometer (LA-ICP-MS) trace element analyses of olivine have been combined with field emission scanning electron microscope (FE-SEM), electron backscatter diffraction (EBSD) and transmission electron microscope (TEM) analyses of micron-size elongated inclusions occurring within deformed olivine ${ }_{1}$. Detailed methodologies are given in the Supplement.

\section{Petrography and electron microscopy of coarse-grained olivine 1 crystals}

Within the Erro-Tobbio replacive troctolite (Troctolite A), the pre-existing matrix of olivine ${ }_{1}$ is characterized by coarsegrained, up to centimetre-size, olivine crystals (Fig. 2). These olivines show intense deformation with the occurrence of numerous parallel subgrain boundaries (Fig. 2a, b, c). Lobate contacts against interstitial plagioclase and clinopyroxene (Fig. 2b, c) testify to the partial dissolution of olivine during the impregnation of the pre-existing dunite and the formation of the replacive troctolite (Basch et al., 2019b).

Microstructural investigation (FE-SEM, EBSD) of the deformed olivine crystals finds evidence of the presence of numerous parallel 10 to $50 \mu \mathrm{m}$ long inclusions (Fig. 2d). These inclusions show a preferred orientation parallel to high-temperature subgrain boundaries of the host olivine (Fig. 2d). They show straight, planar shapes (Figs. 2d, 3a) and occur either at subgrain boundaries or parallel to olivine kink band and subgrain boundaries (Fig. 2d). Additionally, detailed EBSD misorientation maps of single olivine grains show that the inclusions are parallel to crystal dislocations of the host olivine (Fig. 3a). Late serpentine veinlets crosscut the olivine crystal and its inclusions.

SEM-EDS (EDS signifies energy-dispersive X-ray spectroscopy) and EBSD analyses revealed that the planar inclusions are solid and polyphase, mainly formed of amphibole, clinopyroxene and chromite (Figs. 3b, c, S1), with some pore space at the tip of the inclusion (Fig. 3b). The different mineral phases within the inclusions show different crystallographic orientations and do not show any systematic crystallographic orientation with respect to the host olivine (Fig. 3c). Within single inclusions, each phase shows a single orientation (Fig. 3c), suggesting that all portions of a given phase belong to a single interstitial crystal. FESEM backscattered electron (BSE) imaging and TEM highangle annular dark-field (HAADF) images of single inclusions highlighted that they vary in thickness along the inclusion (Fig. 3b; Fig. 4a). Moreover, the walls of the inclusions and the contacts between the mineral phases forming the inclusions are irregular (Figs. 3b, 4a).

FE-SEM EDS and TEM EDX chemical analyses of the mineral phases forming the inclusions (Figs. 3d, $4 \mathrm{~b}, \mathrm{~S} 1)$ revealed that clinopyroxene has a Mg-rich diopsidic composition $\quad(\mathrm{Mg} \#=87.3 \mathrm{~mol} \%-92.8 \mathrm{~mol} \%$; 

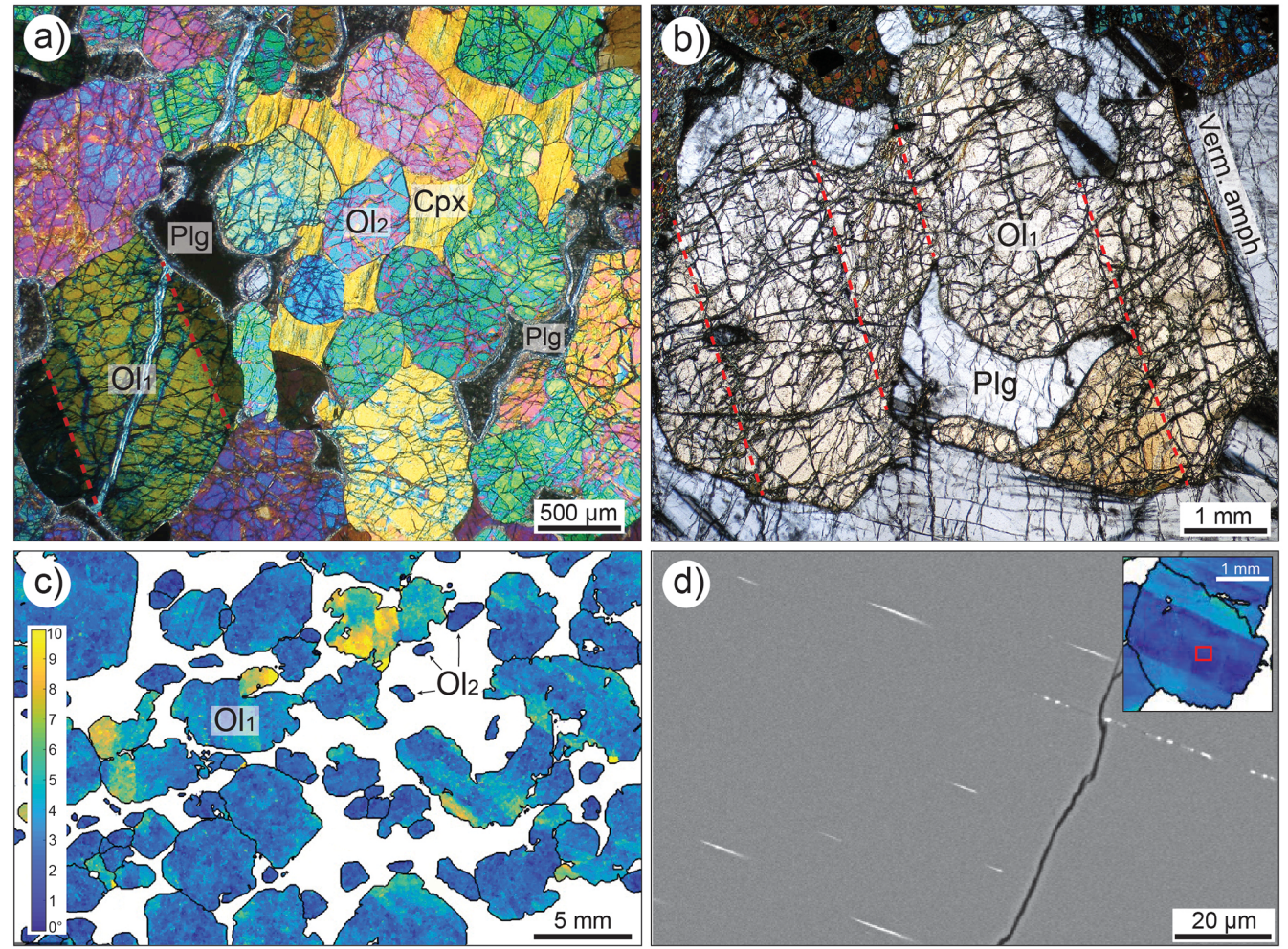

Figure 2. Representative microstructures of the Erro-Tobbio replacive troctolite (a-c) modified from Basch et al. (2019b). (a) Granular olivines (olivine 2 ) embedded in poikilitic clinopyroxene. The largest olivine crystals (olivine 1 ) show the occurrence of kink bands, whose boundaries are highlighted by the red dashed lines. (b) Highly corroded centimetre-size olivine ${ }_{1}$ embedded in poikilitic plagioclase. Vermicular amphibole occurs at the contact between the olivine and plagioclase crystal. (c) EBSD olivine misorientation map showing the textural variability in the olivine matrix. White areas are occupied by interstitial plagioclase and minor clinopyroxene. (d) Backscattered electron image of oriented inclusions (light shaded needles) within a corroded deformed olivine ${ }_{1}$, whose misorientation map is shown in the upper right corner. Notably, the trend of the inclusions and the olivine kink band boundaries show the same orientation.

$\mathrm{Al}_{2} \mathrm{O}_{3}=2.33 \mathrm{wt} \%-3.77 \mathrm{wt} \% ; \quad \mathrm{TiO}_{2}=0.38-0.93 \mathrm{wt} \%$; Supplement S3) and amphiboles are pargasites $(\mathrm{Mg \#}=$ $86.6 \mathrm{~mol} \%-89.7 \mathrm{~mol} \% ; \quad \mathrm{Al}_{2} \mathrm{O}_{3}=10.13 \mathrm{wt} \%-13.13 \mathrm{wt} \%$; $\mathrm{Na}_{2} \mathrm{O}=3.50$ wt $\%-4.60$ wt $\% ; \mathrm{TiO}_{2}=0.28$ wt $\%-0.58$ wt $\%$; Supplement Table S3). It is noteworthy that the pargasitic amphibole is associated with submicron rutile grains (Fig. 4c).

\section{Olivine trace element compositions}

In this section, we document the trace element composition of olivine within all the studied lithologies, with a special focus on the textural complexity in the Troctolite A (olivine 1 vs. olivine 2 ). Olivine in situ trace element analyses were performed using a $102 \mu \mathrm{m}$ laser ablation spot size. These analyses document the trace element composition of olivine crystals as "bulk analyses", including the olivine-hosted inclusions documented in the previous section. Although a small spot size $(10-20 \mu \mathrm{m})$ would amplify the contribution of the inclusion within the bulk olivine analyses, the determination of the low trace element concentrations of olivine required a large $102 \mu \mathrm{m}$ spot size.

Olivines in spinel and plagioclase lherzolites show homogeneous compositions in terms of moderately incompatible elements ( $\mathrm{Ni}, \mathrm{Mn}, \mathrm{Zn}, \mathrm{Co})$, consistent with the compositions reported in Alpine-Apennine impregnated lherzolite by Sanfilippo et al. (2014) and Rampone et al. (2016). They are characterized by high Ni (2815-3571 ppm; Fig. 5a) and relatively low Mn (1087-1167 ppm; Fig. 5b), Zn (2961 ppm; Fig. 5c) and Co (141-158 ppm; Fig. 5d) concentrations. Olivines in olivine gabbros define a wide compositional range, well correlated with their Forsterite content. They exhibit a positive correlation between Forsterite content $(81.3 \mathrm{~mol} \%-89.2 \mathrm{~mol} \%)$ and $\mathrm{Ni}$ concentrations (973$2356 \mathrm{ppm}$; Fig. 5a) and a negative correlation with $\mathrm{Mn}$ (1329-2198 ppm; Fig. 5b), Zn (56-112 ppm; Fig. 5c) and Co (132-198 ppm; Fig. 5d). All olivines (olivine $1+$ olivine $_{2}$ ) in the olivine-rich troctolites display $\mathrm{Ni}(1627-2689 \mathrm{ppm}$; Fig. 5a), Mn (1340-1855 ppm; Fig. 5b), Zn (35-74 ppm; Fig. 5c) and Co (122-173 ppm; Fig. 5d) compositions that 

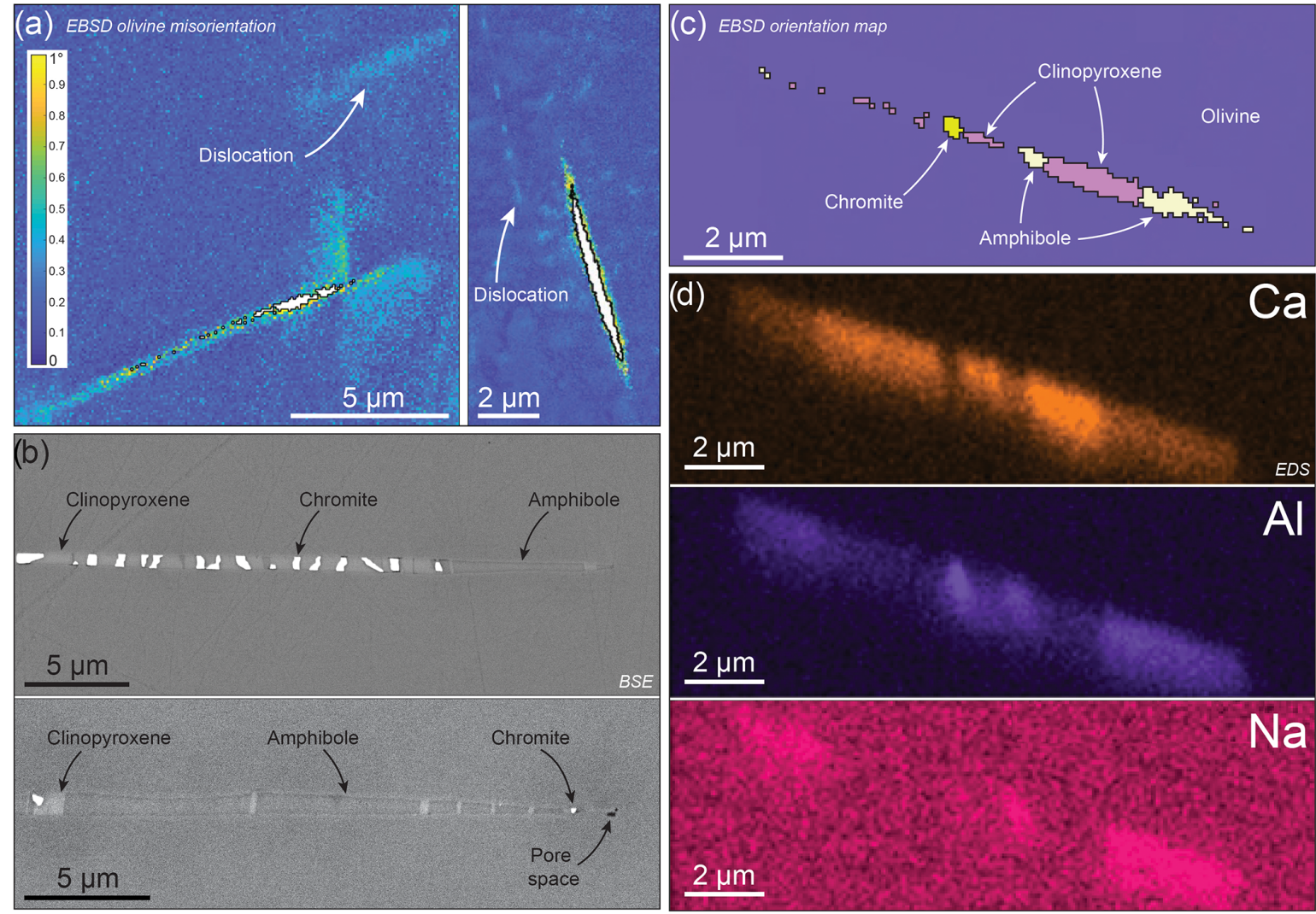

Figure 3. Representative microstructural occurrence of the polyphase inclusions. (a) EBSD olivine misorientation maps of inclusions and host olivine. The olivine crystallographic lattice shows misorientation associated with and parallel to the elongated inclusion. (b) Backscattered electron image of a polyphase inclusion, showing the irregular contacts between the inclusion and olivine host and between the phases forming the inclusion. The lower image shows the occurrence of a pore space at the tip of the inclusion. (c) EBSD orientation map showing the polyphase composition of the inclusion, formed of amphibole, clinopyroxene and chromite, the single orientation of each phase, and the lack of correlation between the orientation of the host olivine and the phases forming the inclusion. (d) $\mathrm{Ca}, \mathrm{Al}$ and $\mathrm{Na}$ EDS chemical maps of a polyphase inclusion.

are intermediate between olivines in the olivine gabbros and in the spinel and plagioclase lherzolites.

Highly incompatible elements in olivine do not follow a linear trend of correlation with the Forsterite content between all lithotypes (Fig. 6). Olivines in spinel and plagioclase lherzolites show low HREE (heavy rare earth element) abundances $\left(\mathrm{Yb}_{N}=0.015-0.303\right.$; Fig. 6a; $N=$ normalized to $\mathrm{C} 1$ chondrite based on Sun and McDonough, 1989) and low Y (0.008-0.08 ppm; Fig. 6b), Ti (11-61 ppm; Fig. 6c) and $\mathrm{Zr}$ concentrations (0.004-0.016 ppm; Fig. 6d), similar to the mantle olivine trace element concentrations reported by Demouchy and Alard (2021). Olivines in the olivine gabbros display modest variations of incompatible trace element abundances despite their significant range of Forsterite content $(81.3 \mathrm{~mol} \%-89.2 \mathrm{~mol} \%)$. They show low HREE abundances $\left(\mathrm{Yb}_{N}=0.09-0.73\right.$; Fig. 6a) and low $\mathrm{Y}$ (0.018-0.128 ppm; Fig. 6b), Ti (43-172 ppm; Fig. 6c) and Zr concentrations (0.001-0.229 ppm; Fig. 6d), consistent with olivine trace element compositions reported in oceanic MORB settings (Ferrando et al., 2018) and in the Erro-
Tobbio olivine gabbros (Rampone et al., 2016). On the other hand, olivines in olivine-rich troctolites and associated dunites show significant trace element variations at relatively constant Forsterite contents $(\mathrm{Fo}=87.3 \mathrm{~mol} \%-89.2 \mathrm{~mol} \%)$. A clear correlation is observed between the olivine texture and trace element composition, with the strongest enrichments in HREE $\left(\mathrm{Yb}_{N}=0.23-0.91\right.$; Fig. 6a, e), Ti (51349 ppm; Fig. 6b), Y (0.019-0.329 ppm; Fig. 6c) and Zr concentrations (0.001-0.694 ppm; Fig. 6d, e) documented in the most corroded and deformed olivine ${ }_{1}$. Fine-grained granular olivine 2 also shows variable HREE $\left(\mathrm{Yb}_{N}=0.23-0.67\right.$; Fig. 6a, e), Ti (63-224 ppm; Fig. 6b), Y (0.023-0.196 ppm; Fig. 6c) and $\mathrm{Zr}(0.001-0.381$; Fig. 6d) concentrations, although they show weaker trace element enrichments compared to the olivine 1 (Fig. 6). Core-rim analyses, as well as geochemical profiles of up to five analyses within the largest olivine $_{1}$ crystals, did not provide evidence of any systematic chemical zoning within olivine ${ }_{1}$ and olivine 2 . 

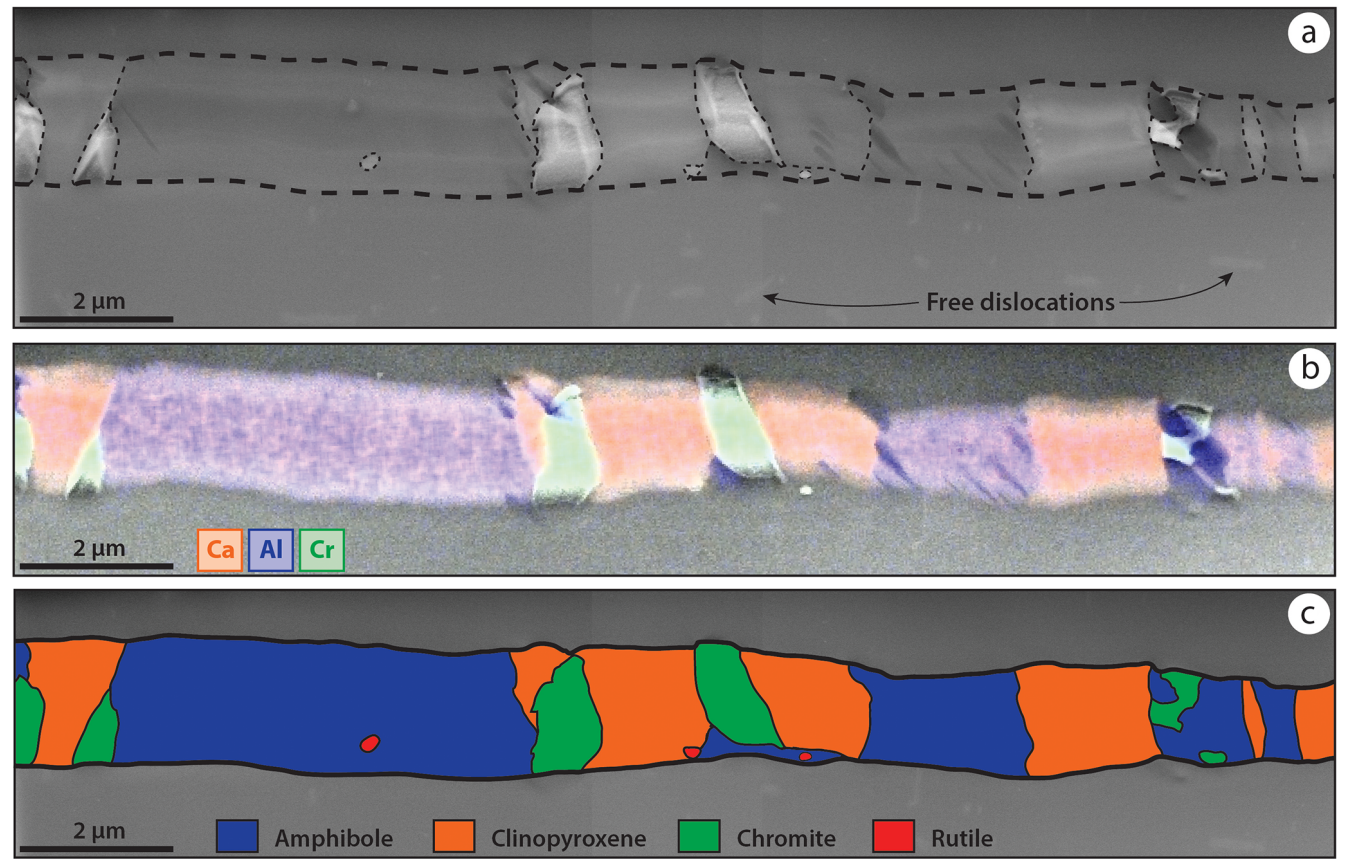

Figure 4. FIB-TEM imaging and chemical mapping of a polyphase inclusion. (a) High-angle annular dark-field image (HAADF) of the inclusion. Free dislocations are evidenced within the olivine host crystal. (b) $\mathrm{Ca}, \mathrm{Al}$ and $\mathrm{Cr}$ EDX elemental mapping. (c) Interpretative line drawing of the polyphase inclusion.

\section{Discussion}

\subsection{Decoupling between olivine texture and trace element composition}

The Erro-Tobbio gabbroic intrusions define trace element compositional trends consistent with the different element compatibilities in olivine $\left(K_{\mathrm{D}-\mathrm{Ni}} \gg K_{\mathrm{D}-\mathrm{Mn}}>K_{\mathrm{D}-\mathrm{Co}, \mathrm{Zn}}\right.$; see De Hoog et al., 2010; Demouchy and Alard, 2021) and with a process of fractional crystallization of MORB-type melts (Figs. 5, 6; Drouin et al., 2009; Rampone et al., 2016). On the other hand, olivines from the olivine-rich troctolite show significant enrichments in the most incompatible trace elements (HREE, Ti, Y, Hf, Zr) at constant Forsterite contents (Fig. 6; Rampone et al., 2016) and were interpreted as being formed by dissolution-precipitation processes during reactive melt percolation within the uppermost lithospheric mantle (Rampone et al., 2016; Basch et al., 2019b). Similar trends were previously documented in other AlpineApennine troctolites (e.g. Sanfilippo et al., 2014; Basch et al., 2018) and interpreted as the result of reactive crystallization. In the Erro-Tobbio troctolites, the melt-rock interaction leading to partial dissolution of a pre-existing dunitic matrix and crystallization of interstitial plagioclase and clinopyroxene occurred at decreasing melt mass during the closure of the magmatic system (Borghini and Rampone, 2007). The related progressive enrichment in incompatible trace elements in the residual melt is evidenced by (i) the saturation of water in the last residual melt fractions and crystallization of vermicular pargasitic amphibole, clinopyroxene and minor orthopyroxene (Borghini and Rampone, 2007; Borghini et al., 2007) and (ii) the trace element zoning recorded in large interstitial clinopyroxene and plagioclase crystals, with increasing concentrations of incompatible elements towards the crystal rims (Borghini and Rampone, 2007). This process is thus expected to result in progressive enrichments in highly incompatible elements in the residual melt and fractionated phases. As pointed out by Rampone et al. (2016), the reaction should involve the dissolution of an olivine ${ }_{1}$, characterized by high forsterite and low incompatible trace element contents and (re-)crystallization of a new olivine, likely enriched in incompatible trace elements. However, Rampone et al. (2016) outlined as an apparent contradiction that the highest trace element contents were shown by resorbed coarse olivines (i.e. olivine ${ }_{1}$ ) rather than the neoformed olivine 2 . Basch et al. (2019b) performed detailed structural analyses of the replacive troctolite and highlighted a formation process of olivine 2 by the disruption and recrystallization of the coarse-grained olivine ${ }_{1}$ during the impregnation of the dunitic matrix.

Our study significantly expands the dataset of olivine trace element compositions in the studied samples (Supplement Table S2) and provides structural evidence allowing us to constrain the decoupling between olivine texture and trace element compositions. Hereafter, we investigate the origin of the polyphase solid inclusions documented within the traceelement-enriched deformed coarse-grained olivines in the 


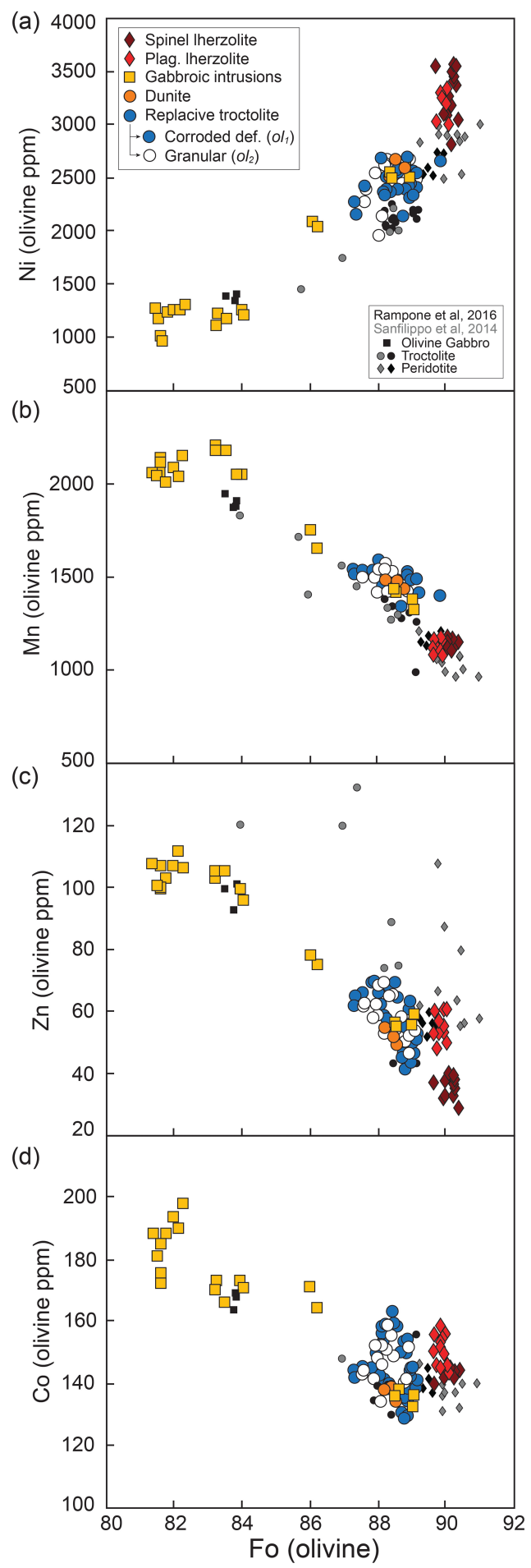

Figure 5. Variation of the moderately incompatible elements as a function of Forsterite content in olivine forming the spinel lherzolite, plagioclase lherzolite, olivine-rich troctolite, dunite and olivine gabbro: (a) Ni, (b) Mn, (c) $\mathrm{Zn}$ and (d) Co. Reference data are olivine compositions in olivine gabbros, troctolites and peridotite from the Erro-Tobbio ultramafic body (Rampone et al., 2016), Internal Ligurides and Lanzo ophiolites (Sanfilippo et al., 2014). context of the replacive formation of the Erro-Tobbio troctolites.

\subsection{Origin of the polyphase inclusions}

In the Erro-Tobbio olivine-rich troctolites, olivine ${ }_{1}$ represents relicts of a pre-existing dunitic matrix (see Basch et al., 2019b) deformed under asthenospheric mantle conditions (i.e. high temperature, low strain; Tommasi et al., 2000). These deformed coarse-grained olivines (olivine 1 ) show the occurrence of numerous elongated planar inclusions oriented parallel to the olivine crystal dislocations and subgrain boundaries (Figs. 2d, 3). They are polyphase, crystalline inclusions mainly formed of pargasitic amphibole, clinopyroxene and chromite (Figs. 3b, c, 4). The inclusionbearing olivines show the strongest enrichments in incompatible trace elements (e.g. Ti, Zr, Yb, Y; see Fig. 6), thus pointing to efficient re-equilibration with the enriched late-stage percolating melt (Rampone et al., 2016). The occurrence of polyphase solid inclusions in olivine crystals has been previously documented in mafic and ultramafic rocks and ascribed to (1) exsolution from the host olivine (e.g. Moseley, 1984; Markl et al., 2001; Ren et al., 2008; Stevens et al., 2010; Xiong et al., 2017) or (2) introduction of a metasomatic fluid within olivine dislocation planes, subgrain boundaries and/or microcrack networks (Drury and VanRoermund, 1989; De Kloe, 2001; Schiano et al., 2006).

In the studied samples, several arguments are against an origin of the inclusions as exsolutions from the host olivine. First, although symplectitic polyphase exsolutions have been described in olivine (e.g. Markl et al., 2001; Stevens et al., 2010), the association between amphibole, clinopyroxene and chromite has never been documented as exsolutions from olivine crystals. Second, in the studied olivines, the contact between the inclusion walls and host olivine and between the phases forming the inclusions is irregular (Figs. 3b, 4 ), whereas the morphology of olivine-hosted exsolutions is typically reported as being tubular to planar in shape with straight contacts between the exsolution and the host olivine and between the exsolved phases (e.g. Moseley, 1984; Otten, 1985; Franz and Wirth, 2000; Markl et al., 2001; Risold et al., 2001; Stevens et al., 2010; Xiong et al., 2017). Third, the crystallographic orientation of the phases forming the studied inclusions do not show any relationship with the orientation of the host olivine (Fig. 3c), whereas crystallographic orientations of exsolved phases are typically correlated to the orientation of the host crystal (e.g. Moseley, 1984; Franz and Wirth, 2000; Mikouchi et al., 2000; Markl et al., 2001; Risold et al., 2001; Xiong et al., 2017). Finally, Fig. 3c shows that the different phases are characterized by different orientations but also indicates a single orientation for all portions of a given phase, in turn suggesting that the latter belong to a single interstitial crystal. This is further evidenced by TEM imaging of a single inclusion (Fig. 4a), in which the phases are highly irregular and show textures of crystal intergrowth. 
In the olivine-rich troctolites, the crystallization of the last trace element-enriched melt fractions is represented by the formation of vermicular clinopyroxene, Ti-rich pargasitic amphibole and minor orthopyroxene at the contact between olivine and the interstitial phases (Fig. 2b; e.g. Borghini and Rampone, 2007; Borghini et al., 2007; Rampone et al., 2016; Basch et al., 2019b). Remarkably, the polyphase inclusions observed in deformed olivine 1 show a mineralogical assemblage similar to the vermicular crystals (Figs. 3b, 4), and the chemical analyses of the phases composing the inclusions indicate an $\mathrm{Mg}$-, $\mathrm{Al}$ - and Ti-rich composition of clinopyroxene and amphibole, similar to the vermicular crystals (Supplement Table S3; Borghini and Rampone, 2007). These morphological and chemical features thus suggest a genetic relationship between the polyphase inclusions and the vermicular phases crystallized at the grain boundaries from the last residual melt fractions during the closure of the magmatic system at near-solidus conditions. Accordingly, we infer that the polyphase planar inclusions testify to the migration of late metasomatic fluids within the deformed olivine crystals. In the following sections, we assess this hypothesis of intracrystalline melt migration and provide a geochemical modelling to link the occurrence of polyphase inclusions to the enriched trace element signature documented in deformed olivines.

\subsection{Formation of the inclusions by metasomatic fluids}

We propose the following scenario to explain the formation of the polyphase inclusions occurring within deformed olivine $_{1}$ in the olivine-rich troctolite: (i) during reactive crystallization of the Erro-Tobbio olivine-rich troctolites, the fractionating melt, progressively decreasing in melt mass, was enriched in trace elements (Borghini et al., 2007; Rampone et al., 2016) until it reached amphibole saturation in the last melt fractions $(<5 \%$ residual melt mass; Borghini and Rampone, 2007); (ii) the residual melts crystallized thin vermicular orthopyroxene, clinopyroxene and Ti-pargasite around olivine grains during the progressive closure of the porosity (Fig. 7a); and (iii) the evolved and volatile-rich character of the last melt films likely increased the reactivity of the melt towards the olivine matrix, in turn favouring dissolution along subgrain boundaries and dislocations (e.g. Suhr et al., 2008; Drouin et al., 2010; Ferrando et al., 2018) and allowing the volatile-rich melt to percolate into the deformed olivine ${ }_{1}$ crystals (Fig. 7b; e.g. Cmiral et al., 1998; De Kloe et al., 2000; Konrad-Schmolke et al., 2018). The presence of polyphase inclusions not only along olivine subgrain boundaries but also within olivine subgrains indicates that the evolved melts also percolated within the olivine crystal along iso-oriented dislocations (see Karato, 1987; Wang et al., 2016) rather than along subgrain boundaries only (Figs. 2d, 3a).

The planar lens-shaped morphology of the inclusions and the occurrence of pore space at their tip (Fig. 3) indicate a propagation within the deformed olivine crystal that is likely accommodated by microfracturing in the direction of the elongation of the inclusion (Fig. 7c; Scholz, 2019) as the result of increased fluid-induced stress at the tips of the meltfilled microcrack (e.g. Rubin, 1995; Scholtz, 2019). During the intracrystalline melt migration, the volatile-rich melt precipitated chromite, pargasitic amphibole and clinopyroxene (Figs. 3b, c, 4; Supplement Table S3) similar in composition to vermicular amphibole and clinopyroxene documented around olivine crystals (Borghini and Rampone, 2007). The absence of vermicular chromite around olivine crystals most likely results from the partial recrystallization of the preexisting chromite crystals within the troctolitic matrix, as indicated by their high Ti contents (see Borghini and Rampone, 2007). Also, slightly lower $\mathrm{TiO}_{2}$ contents in amphibole within the polyphase inclusion can be explained by the precipitation of submicron rutile grains (Fig. 4c) stabilized by the evolved and volatile-rich character of the percolating melt (e.g. Foley et al., 2000; Lorand and Gregoire, 2010).

\subsection{Implications of intracrystalline percolation process}

Within the Erro-Tobbio olivine-rich troctolite, the inclusionbearing deformed olivine ${ }_{1}$ matrix is characterized by systematic "bulk" enrichments of highly incompatible elements (Fig. 6; HREE, Ti, Y, Hf, Zr). Such enrichments could in principle result from either (i) "mixed" compositions that include olivine $(>99 \%)+$ polyphase inclusions $(<1 \%)$ as a result of the large spot size used for LA-ICP-MS analyses $(102 \mu \mathrm{m})$ or (ii) fast diffusive re-equilibration between the deformed olivine grain and an evolved intracrystalline melt phase (e.g. Zhang and Cherniak, 2010; Costa et al., 2020).

To assess the impact of the presence of inclusions in the LA-ICP-MS spot analysis (i.e. mixed analyses) on the olivine trace element composition, we computed the trace element enrichments resulting from the contribution of $0.01 \mathrm{vol} \%$ to $2 \mathrm{vol} \%$ of amphibole inclusions to an olivine composition. To compute this "mixing trend" (Fig. 8), we used the composition of the olivine 1 showing the lowest trace element concentration $\left(\mathrm{Zr}_{N} / \mathrm{Dy}_{N}=0.38 ; \mathrm{Yb}_{N}=0.169\right)$ and the trace element composition of a vermicular amphibole (based on Borghini and Rampone, 2007) as being representative of the polyphase inclusions. The mixed patterns display significant HREE enrichments at constant $\mathrm{Zr}_{N} / \mathrm{Dy}_{N}$ when the volume of inclusion contributing to the olivine trace element composition exceeds 0.1 vol \% (Fig. 8). Additionally, the progressive addition of amphibole in the mixed patterns leads to a strong increase in LREE / HREE (LREE signifies light rare earth elements) ratios at increasing inclusion volume (Fig. S2). Although the mixing trend accounts for the olivine ${ }_{1}$ compositions showing moderate enrichments in highly incompatible trace elements, it does not reproduce the strong trace element enrichments and low values of LREE / HREE fractionation observed in the most deformed olivines (Figs. 6, S2). 

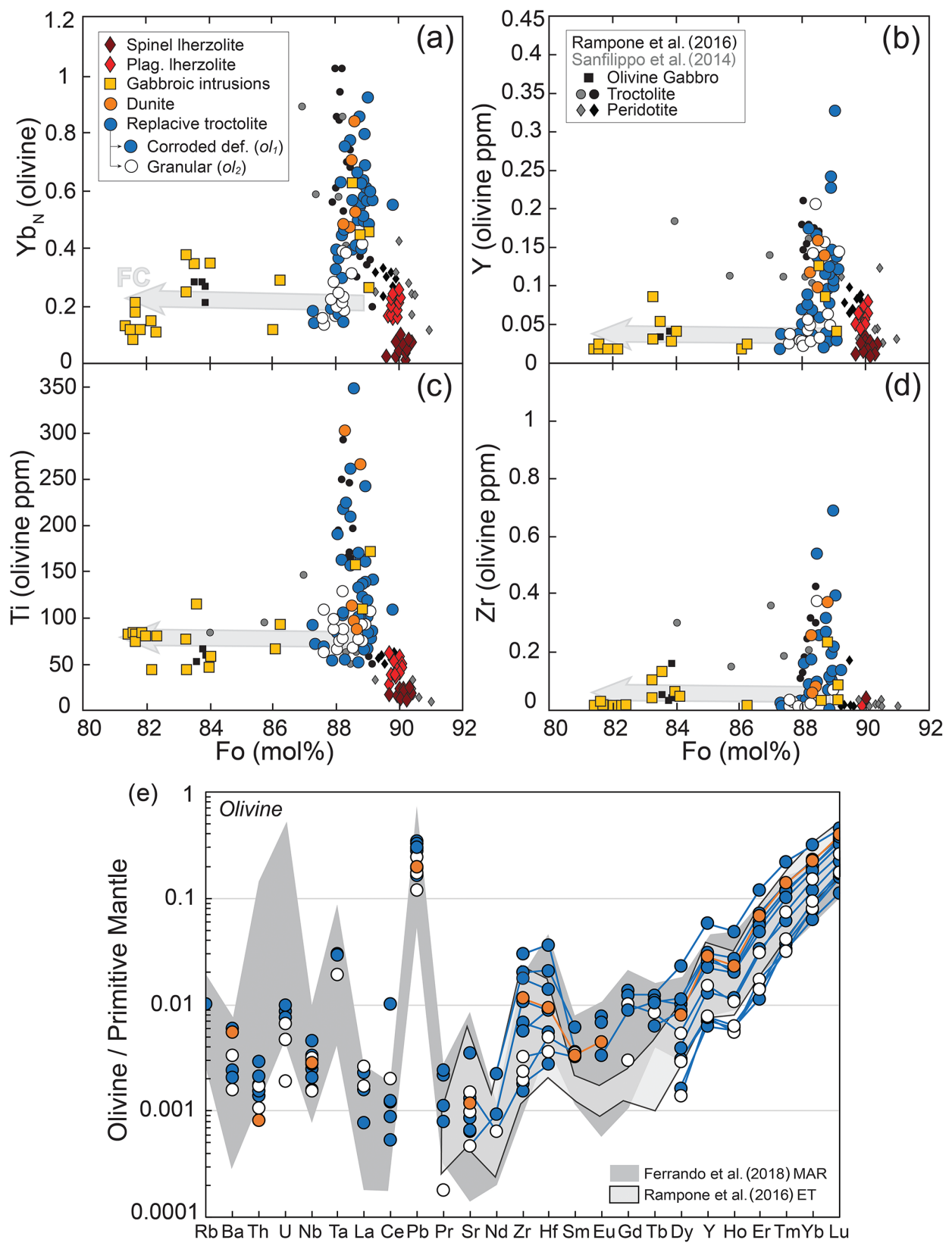

Figure 6. Olivine trace element compositions within the Erro-Tobbio ultramafic body. Forsterite (mol \%) vs. (a) $\mathrm{Yb}_{N}$ normalized to $\mathrm{C} 1$, (b) $\mathrm{Y}$ (ppm), (c) Ti (ppm) and (d) $\mathrm{Zr}$ (ppm). (e) Trace element contents normalized to primitive mantle. Reference data points and compositional fields represent olivine compositions in olivine gabbros, troctolites and peridotites from the Erro-Tobbio (Rampone et al., 2016), Internal Ligurides and Lanzo ophiolites (Sanfilippo et al., 2014), as well as the Mid-Atlantic Ridge (Ferrando et al., 2018). Fractional crystallization (FC) trends, defined by grey arrows, are based on Sanfilippo et al. (2014). Normalization values are based on Sun and McDonough (1989).

As demonstrated by Rampone et al. (2016), the dissolution-precipitation process involved in the formation of the olivine-rich troctolites leads to $\mathrm{Zr}-\mathrm{Hf}$ specific enrichments and to increasing $\mathrm{Zr}_{N} / \mathrm{REE}_{N}$ fractionation at constant LREE/HREE fractionation upon melt differentiation. They modelled an assimilation-fractional crystallization process (AFC; De Paolo, 1981) involving the partial dissolution of the olivine matrix during the crystallization of interstitial plagioclase and successfully reproduced the strongest trace element enrichments documented in the most deformed olivine $_{1}$. Figure 8 reports similar AFC models performed at varying assimilated mass / crystallized mass ratios $(\mathrm{Ma} / \mathrm{Mc}=0.5-0.99)$ and computed using the following parameters: (i) the initial melt ${ }_{1}$ composition is the melt in equilibrium with the clinopyroxene showing the lowest REE concentrations within the olivine-rich troctolites; (ii) the model 

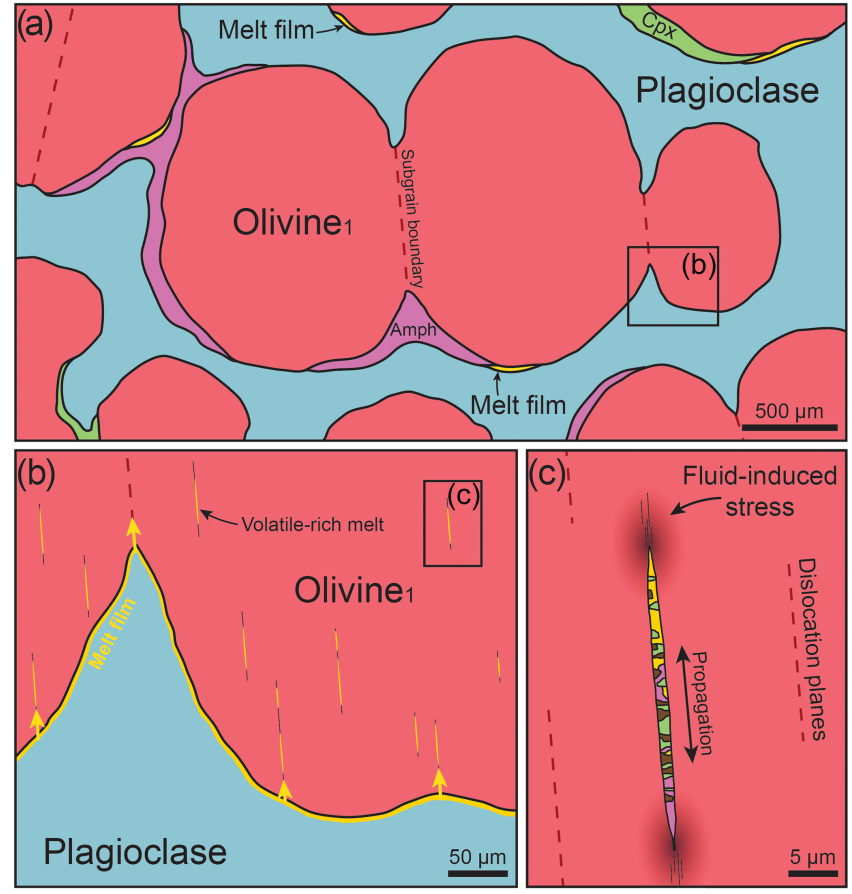

Figure 7. Representative sketch of the formation process of the polyphase inclusion. (a) Progressive closure of the porosity during reactive formation of the troctolite leads to the crystallization of vermicular amphibole, clinopyroxene and minor orthopyroxene as late magmatic phases. (b) The residual volatile-rich melt films at the contact between olivine and plagioclase are forced inside the deformed olivine crystal, along subgrains and dislocations, in turn leading to intracrystalline percolation. (c) Detail of the inclusion, whose shape leads to increased fluid-induced stress at its tips, in turn allowing for microfracturing and forward propagation of the inclusion.

assumes assimilation of the olivine matrix $(\mathrm{Ma}=100 \%$ olivine) and crystallization of plagioclase ( $\mathrm{Mc}=100 \%$ plagioclase) by the initial melt composition; (iii) the assimilated material is an olivine from the country peridotite MF40 (based on Rampone et al., 2016); and (iv) the partition coefficients used for the AFC models are based on Kennedy et al. (1993) for olivine and after Bédard (2001) for plagioclase. At progressively increasing assimilated mass of olivine, the AFC models predict stronger enrichments in $\mathrm{Zr}_{N} / \mathrm{Dy}_{N}$ and lower variations in $\mathrm{Yb}_{N}$ at decreasing melt mass. Consistent with the previously documented results, the Erro-Tobbio deformed olivines (olivine 1 ) showing the strongest trace element enrichments follow an AFC trend characterized by high assimilated mass / crystallized mass ratios $(\mathrm{Ma} / \mathrm{Mc}=0.98$ 0.99; Fig. 8; Rampone et al., 2016).

We emphasize that the enriched character of the deformed olivine $_{1}$ does not result from the crystallization of these olivines from the residual melt but rather from diffusive re-equilibration of the pre-existing olivine matrix with the evolved melt residual after the reactive crystallization of the Erro-Tobbio olivine-rich troctolites. Although trace element re-equilibration in olivine is fast in deformed crystals (Burgess and Cooper, 2013) at magmatic to sub-magmatic temperatures (e.g. Ferrando et al., 2020), we infer that the reequilibration of such coarse centimetre-size crystals was possible only because of the presence of intracrystalline melts percolating through the deformed olivine crystals, as evidenced by the occurrence of the polyphase inclusions within olivine . $_{\text {. }}$.

The strong trace element enrichments reported in the preexisting matrix is a direct consequence of the intracrystalline melt migration process enhancing diffusive re-equilibration of coarse deformed crystals. This in turn suggests that the latter process can lead to efficient diffusive re-equilibration at large scale and possibly account for part of the cryptic metasomatism documented in the oceanic upper mantle and lower crust.

\section{$7 \quad$ Summary and conclusions}

The formation of the Erro-Tobbio olivine-rich troctolites involved extensive dissolution-precipitation reactions between a pre-existing dunitic matrix and a percolating MORB-type melt. This reactive melt migration process led to progressive trace element enrichments in the residual melt. Unexpectedly, this trace element enrichment is documented in coarse deformed olivines texturally corresponding to the preexisting dunitic matrix. Interestingly, trace element enrichments in deformed olivine crystals are systematically correlated with the occurrence of 10 to $50 \mu \mathrm{m}$ long elongated polyphase inclusions oriented parallel to the host olivine subgrain boundaries. These inclusions are mainly formed of amphibole, clinopyroxene and chromite and show irregular contacts with the host crystal and between the phases forming the inclusion. We interpret these inclusions as testifying to a process of intracrystalline melt migration, during which melts evolve to become residuals after the reactive crystallization of the olivine-rich troctolites percolated within the most deformed olivine crystals along subgrain boundaries and iso-oriented crystal dislocations. We infer that the presence of intracrystalline melt greatly enhanced the diffusive re-equilibration of the percolated crystals, thus acquiring the enriched character expected in neoformed olivine crystals. This grain-scale melt migration process has strong geochemical implications and can lead to the efficient re-equilibration of a percolated rock.

Data availability. All data derived from this research are available in the Supplement and upon request to the corresponding author.

Supplement. The supplement related to this article is available online at: https://doi.org/10.5194/ejm-33-463-2021-supplement. 


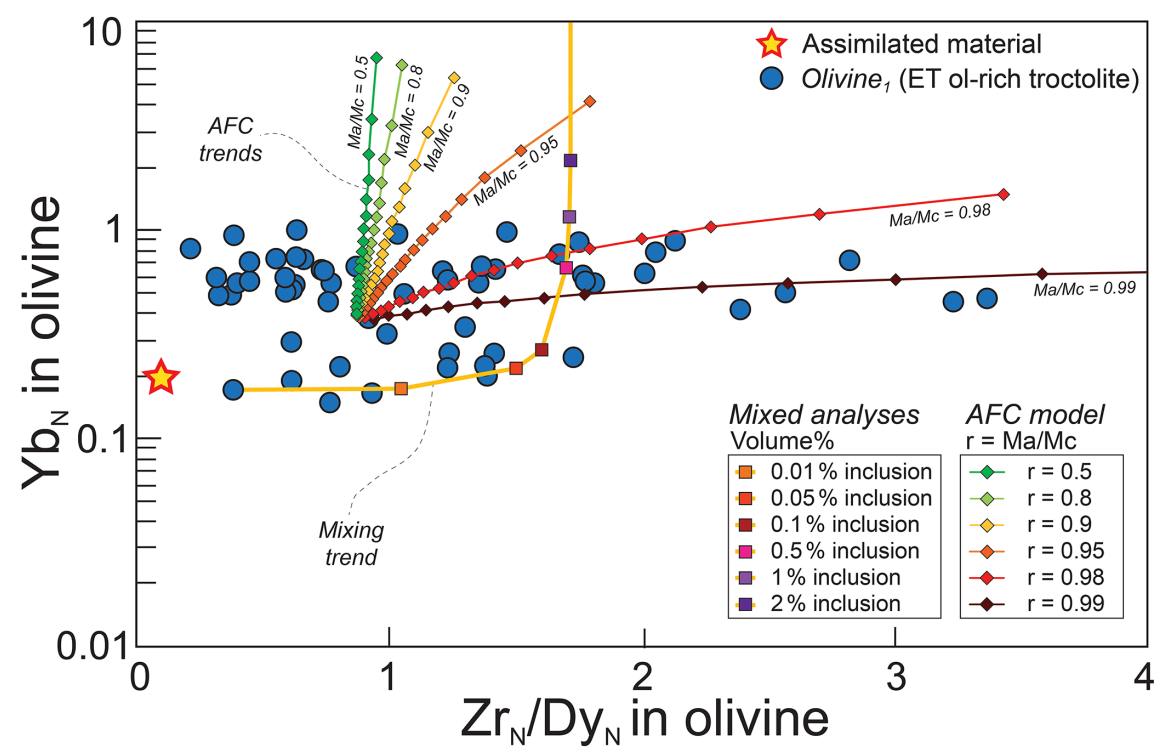

Figure 8. Variations of $\mathrm{Zr}_{N} / \mathrm{Dy}_{N}$ vs. $\mathrm{Yb}_{N}$ in olivine ${ }_{1}$ crystals from the Erro-Tobbio olivine-rich troctolite, compared to olivine compositions in equilibrium with the residual melt composition after assimilation-fractional crystallization (AFC) processes, computed at varying assimilated mass / crystallized mass ratios $(\mathrm{Ma} / \mathrm{Mc}=0.5-0.99)$ and decreasing melt mass $(F$ decreasing from 1 to 0.1$)$. The partition coefficients are based on Kennedy et al. (1993) for olivine and Bédard (2001) for plagioclase. Also represented is a "mixing trend" representing progressively increasing contribution of vermicular amphibole composition (from $0.01 \mathrm{vol} \%$ to $2 \mathrm{vol} \%$ ) in olivine trace element composition. C1 chondrite normalization values are based on Sun and McDonough (1989).

Author contributions. All authors provided reviews during the manuscript production process. VB performed FE-SEM, EBSD, LA-ICP-MS and TEM analyses and wrote the manuscript; MRD, $\mathrm{OP}$ and EH provided assistance with the TEM analyses; FB provided assistance with the EBSD analyses; MG provided assistance with the LA-ICP-MS analyses; LC and ER discussed the data and organized the manuscript, together with VB.

Competing interests. The authors declare that they have no conflict of interest.

Disclaimer. Publisher's note: Copernicus Publications remains neutral with regard to jurisdictional claims in published maps and institutional affiliations.

Acknowledgements. We thank Fatma Kourim, Michel Grégoire and an anonymous reviewer for constructive reviews that improved the quality of this manuscript and Didier Laporte and Patrick Cordier for their work as editors. We thank Paolo Campanella and Alessandra Gavoglio, as well as Christophe Nevado and Doriane Delmas, for the realization of the thin section and the high-quality polishing. We also thank Laura Negretti for assistance with the FE-SEM analyses.
Financial support. This research has been supported by FP7 People: Marie Curie Actions (REA grant agreement no. 608001) and Horizon 2020 (EPOS IP, grant no. 676564).

Review statement. This paper was edited by Didier Laporte and reviewed by Fatma Kourim, Michel Grégoire and one anonymous referee.

\section{References}

Basch, V., Rampone, E., Crispini, L., Ferrando, C., Ildefonse, B., and Godard, M.: From mantle peridotites to hybrid troctolites: textural and chemical evolution during melt-rock interaction history (Mt. Maggiore, Corsica, France), Lithos, 323, 4-23, https://doi.org/10.1016/j.lithos.2018.02.025, 2018.

Basch, V., Rampone, E., Borghini, G., Ferrando, C., and Zanetti, A.: Origin of pyroxenites in the oceanic mantle and their implications on the reactive percolation of depleted melts, Contrib. Mineral. Petr., 174, 97, https://doi.org/10.1007/s00410-019-1640-0, 2019a.

Basch, V., Rampone, E., Crispini, L., Ferrando, C., Ildefonse, B., and Godard, M.: Multi-stage reactive formation of troctolites in slow-spreading oceanic lithosphere (Erro-Tobbio, Italy): a combined field and petrochemical study, J. Petrol., 60, 873-906, https://doi.org/10.1093/petrology/egz019, 2019b.

Bédard, J. H.: Parental magmas of the Nain Plutonic Suite anorthosites and mafic cumulates: a trace element modelling approach, Contrib. Mineral. Petrol., 141, 747-771, https://doi.org/10.1007/s004100100268, 2001. 
Borghini, G. and Rampone, E.: Postcumulus processes in oceanictype olivine-rich cumulates: the role of trapped melt crystallization versus melt-rock interaction, Contrib. Mineral. Petr., 154, 619-633, https://doi.org/10.1007/s00410-007-0217-5, 2007.

Borghini, G., Rampone, E., Crispini, L., De Ferrari, R., and Godard, M.: Origin and emplacement of ultramafic-mafic intrusions in the Erro-Tobbio mantle peridotite (Ligurian Alps, Italy), Lithos, 94, 210-229, https://doi.org/10.1016/j.lithos.2006.06.014, 2007.

Burgess, K. D. and Cooper, R. F.: Extended planar defects and the rapid incorporation of $\mathrm{Ti}^{4+}$ into olivine, Contrib. Mineral. Petr., 166, 1223-1233, https://doi.org/10.1007/s00410-0130918-x, 2013

Cmiral, M., Fitz Gerald, J. D., Faul, U. H., and Green, D. H.: A close look at dihedral angles and melt geometry in olivine-basalt aggregates: a TEM study, Contrib. Mineral. Petr., 130, 336-345, https://doi.org/10.1007/s004100050369, 1998.

Collier, M. L. and Kelemen, P. B.: The case for reactive crystallization at mid-ocean ridges, J. Petrol., 51, 1913-1940, https://doi.org/10.1093/petrology/egq043, 2010.

Costa, F., Dohmen, R., and Chakraborty, S.: Timescales of magmatic processes from modeling the zoning patterns of crystals, Rev. Mineral. Geochem., 69, 545-594, https://doi.org/10.2138/rmg.2008.69.14, 2008.

Costa, F., Shea, T., and Ubide, T.: Diffusion chronometry and the timescales of magmatic processes, Nature Reviews, 1, 201-214, https://doi.org/10.1038/s43017-020-0038-x, 2020.

De Hoog, J. C. M., Gall, L., and Cornell, D. H.: Trace-element geochemistry of mantle olivine and application to mantle petrogenesis and geothermobarometry, Chem. Geol., 270, 196-215, https://doi.org/10.1016/j.chemgeo.2009.11.017, 2010.

De Kloe, R.: Deformation mechanisms and melt nanostructures in experimentally deformed olivine-orthopyroxene rocks with low melt fractions, PhD thesis, University of Utrecht, 176 pp., 2001.

De Kloe, R., Drury, M. R., and Van Roermund, H. L. M.: Evidence for stable grain boundary melt films in experimentally deformed olivine-orthopyroxene rocks, Phys. Chem. Miner., 27, 480-494, https://doi.org/10.1007/s002690000090, 2000.

Demouchy, S. and Alard, O.: Hydrogen, trace, and ultra-trace element distribution in natural olivines, Contrib. Miner. Petrol., 176, 26, https://doi.org/10.1007/s00410-021-01778-5, 2021.

De Paolo, D. J.: Trace elements and isotopic effects of combined wall rock assimilation and fractional crystallization, Earth Planet. Sc. Lett., 53, 189-202, https://doi.org/10.1016/0012821X(81)90153-9, 1981.

Drouin, M., Godard, M., Ildefonse, B., Bruguier, O., and Garrido, C. J.: Geochemical and petrographic evidence for magmatic impregnation in the oceanic lithosphere at Atlantis Massif, MidAtlantic Ridge (IODP hole U1309D, 30 N), Chem. Geol., 264, 71-88, https://doi.org/10.1016/j.chemgeo.2009.02.013, 2009.

Drouin, M., Ildefonse, B., and Godard, M.: A microstructural imprint of melt impregnation in slow spreading lithosphere: Olivine-rich troctolites from the Atlantis Massif, Mid-Atlantic Ridge, $30^{\circ}$ N, IODP Hole U1309D, Geochem. Geophy. Geosy., 11, Q06003, https://doi.org/10.1029/2009GC002995, 2010.

Drury, M. R. and Van Roermund, H. L. M.: Metasomatic origin for Fe-Ti-rich multiphase inclusions in olivine from kimberlite xenoliths, Geology, 16, 1035-1038, https://doi.org/10.1130/00917613(1988)016<1035:MOFFTR>2.3.CO;2, 1989.
Ferrando, C., Godard, M., Ildefonse, B., and Rampone, E.: Melt transport and mantle assimilation at Atlantis Massif (IODP Site U1309): constraints from geochemical modelling, Lithos, 323, 24-43, https://doi.org/10.1016/j.lithos.2018.01.012, 2018.

Ferrando, C., Lynn, K. J., Basch, V., Godard, M., and Ildefonse, B.: Retrieving timescales of oceanic crustal evolution at slow-spreading centres: Insights from modelling of geochemical profiles in olivine, Lithos, 376-377, 105727, https://doi.org/10.1016/j.lithos.2020.105727, 2020.

Ferrando, C., France, L., Basch, V., Sanfilippo, A., Tribuzio, R., and Boulanger, M.: Grain size variations record segregation of residual melts in slow-spreading oceanic crust (Atlantis Bank, $57^{\circ}$ E Southwest Indian Ridge), J. Geophys. Res.-Sol. Ea., 126, e2020JB020997, https://doi.org/10.1029/2020JB020997, 2021.

Foley, S. F., Barth, M. G., and Jenner, G. A.: Rutile/melt partition coefficients for trace elements and an assessment of the influence of rutile on the trace element characteristics of subduction zone magmas, Geochim. Cosmochim. Ac., 64, 933-938, https://doi.org/10.1016/S0016-7037(99)00355-5, 2000.

Franz, L. and Wirth, R.: Spinel inclusions in olivine of peridotite xenoliths from TUBAF seamount (Bismarck Archipelago/Papua New Guinea): evidence for the thermal and tectonic evolution of the oceanic lithosphere, Contrib. Mineral. Petr., 140, 283-295, https://doi.org/10.1007/s004100000188, 2000.

Hebert, L. B. and Montési, L. G. J.: Generation of permeability barriers during melt extraction at midocean ridges, Geochem. Geophy. Geosy., 11, Q12008, https://doi.org/10.1029/2010GC003270, 2010.

Higgie, K. and Tommasi, A.: Feedbacks between deformation and melt distribution in the crust-mantle transition zone of the Oman ophiolite, Earth Planet. Sc. Lett., 359-360, 61-72, https://doi.org/10.1016/j.epsl.2012.10.003, 2012.

Karato, S.: Scanning electron microscope observation of dislocations in olivine, Phys. Chem. Miner., 14, 245-248, https://doi.org/10.1007/BF00307989, 1987.

Kelemen, P. B., Hirth, G., Shimizu, N., Spiegelman, M., and Dick H. J. B.: A review of melt migration processes in the adiabatically upwelling mantle beneath oceanic spreading ridges, Philos. T. Roy. Soc. A, 355, 283-318, https://doi.org/10.1098/rsta.1997.0010, 1997.

Kennedy, A. K., Lofgren, G. E., and Wasserburg, G. J.: An experimental study of trace element partitioning between olivine, orthopyroxene and melt in chondrules: equilibrium values and kinetic effects, Earth Planet. Sc. Lett., 115, 177-195, https://doi.org/10.1016/0012-821X(93)90221-T, 1993.

Konrad-Schmolke, M., Halama, R., Wirth, R., Thomen, A., K1itscher, N., Morales, L., Schreiber, A., and Wilke, F. D. H.: Mineral dissolution and reprecipitation mediated by an amorphous phase, Nat. Commun., 9, 1637, https://doi.org/10.1038/s41467018-03944-z, 2018.

Liang, Y.: Kinetics of crystal-melt reaction in partially molten silicates: 1. Grain scale processes, Geochem. Geophy., Geosy., 4, GC000375, https://doi.org/10.1029/2002GC000375, 2003.

Lorand, J.-P. and Gregoire, M.: Petrogenesis of Fe-Ti oxides in amphibole-rich veins from the Lherz orogenic peridotite (Northeastern Pyrénées, France), Contrib. Mineral. Petr., 160, 99-113, https://doi.org/10.1007/s00410-009-0468-4, 2010.

Manatschal, G. and Müntener, O.: A type sequence across an ancient magma-poor ocean-continent transition: the example of 
the western Alpine Tethys ophiolites, Tectonophysics, 73, 4-19, https://doi.org/10.1016/j.tecto.2008.07.021, 2009.

Markl, G., Marks, M., and Wirth, R.: The influence of $T, a_{\mathrm{SiO} 2}$, and $f_{\mathrm{O} 2}$ on exsolution textures in Fe-Mg olivine: An example from augite syenites of the Ilimaussaq Intrusion, South Greenland, Am. Mineral., 86, 36-46, https://doi.org/10.2138/am-20010105, 2001.

Mikouchi, T., Yamada, I., and Miyamoto, M.: Symplectic exsolution in olivine from the Nakhla martian meteorite, Meteoritics and Planetary Science, 35, 937-942, https://doi.org/10.1111/j.1945-5100.2000.tb01483.x, 2000.

Morgan, Z. and Liang, Y.: An experimental study of the kinetics of lherzolite reactive dissolution with applications to melt channel formation, Contrib. Mineral. Petr., 150, 369-385, https://doi.org/10.1007/s00410-005-0033-8, 2005.

Moseley, D.: Symplectitic exsolution in olivine, Am. Mineral., 69, 139-153, 1984.

Otten, M. T.: The subsolidus history of the Artfjället gabbro: a TEM study of olivine, augite and orthopyroxene, J. Petrol., 26, 488514, https://doi.org/10.1093/petrology/26.2.488, 1985.

Piccardo, G. B.: Evolution of the lithospheric mantle during passive rifting: Inferences from the Alpine-Apennine orogenic peridotites, Gondwana Res., 39, 230-249, https://doi.org/10.1016/j.gr.2016.03.001, 2016.

Piccardo, G. B. and Guarnieri, L.: Alpine peridotites from the Ligurian Tethys: an updated critical review, International Geological Review, 52, 1138-1159, https://doi.org/10.1080/00206810903557829, 2010.

Piccardo, G. B. and Vissers, R. L. M.: The pre-oceanic evolution of the Erro-Tobbio peridotite (Voltri Massif, Ligurian Alps, Italy), J. Geodyn., 43, 417-449, https://doi.org/10.1016/j.jog.2006.11.001, 2007.

Rampone, E. and Borghini, G.: Melt migration and intrusion in the Erro-Tobbio peridotites (Ligurian Alps, Italy): insights on magmatic processes in extending lithospheric mantle, Eur. J. Mineral., 20, 573-585, https://doi.org/10.1127/09351221/2008/0020-1807, 2008.

Rampone, E. and Sanfilippo, A.: The Heterogeneous Tethyan Oceanic Lithosphere of the Alpine Ophiolites, Elements, 17, 2328, https://doi.org/10.2138/gselements.17.1.23, 2021.

Rampone, E., Romairone, A., and Hofmann, A. W.: Contrasting bulk and mineral chemistry in depleted peridotites: evidence for reactive porous flow, Earth Planet. Sc. Lett., 218, 491-506, https://doi.org/10.1016/S0012-821X(03)00679-4, 2004.

Rampone, E., Romairone, A., Abouchami, W., Piccardo, G. B., and Hofmann, A. W.: Chronology, petrology and isotope geochemistry of the Erro-Tobbio peridotites (Ligurian Alps, Italy): records of late Paleozoic lithospheric extension, J. Petrol., 46, 799-827, https://doi.org/10.1093/petrology/egi001, 2005.

Rampone, E., Borghini, G., Romairone, A., Abouchami, W., Class, C., and Goldstein, S. L.: Sm-Nd geochronology of the Erro-Tobbio gabbros (Ligurian Alps, Italy): insights into the evolution of the Alpine Tethys, Lithos, 205, 236-246, https://doi.org/10.1016/j.lithos.2014.07.012, 2014.

Rampone, E., Borghini, G., Godard, M., Ildefonse, B., Crispini, L., and Fumagalli, P.: Melt/rock reaction at oceanic peridotite/gabbro transition as revealed by trace element chemistry of olivine, Geochim. Cosmochim. Ac., 190, 309-331, https://doi.org/10.1016/j.gca.2016.06.029, 2016.
Rampone, E., Borghini, G., and Basch, V.: Melt migration and meltrock reaction in the Alpine-Apennine peridotites: Insights on mantle dynamics in extending lithosphere, Geosci. Front., 11, 151-166, https://doi.org/10.1016/j.gsf.2018.11.001, 2020.

Ren, Y., Chen, F., Yang, J., and Gao, Y.: Exsolutions of Diopside and Magnetite in Olivine from Mantle Dunite, Luobusa Ophiolite, Tibet, China, Acta Geol. Sin., 82, 377-384, https://doi.org/10.1111/j.1755-6724.2008.tb00587.x, 2008.

Risold, A.-C., Trommsdorff, V., and Grobéty, B.: Genesis of ilmenite rods and palisades along humite-type defects in olivine from Alpe Arami, Contrib. Mineral. Petr., 140, 619-628, https://doi.org/10.1007/s004100000204, 2001.

Rubin, A. M.: Propagation of magma-filled cracks, Annu. Rev. Earth Pl. Sc., 23, 287-336, https://doi.org/10.1146/annurev.ea.23.050195.001443, 1995.

Sanfilippo, A., Tribuzio, R., and Tiepolo, M.: Mantle-crust interactions in the oceanic lithosphere: constraints from minor and trace elements in olivine, Geochim. Cosmochim. Ac., 141, 423-439, https://doi.org/10.1016/j.gca.2014.06.012, 2014.

Saper, L. and Liang, Y.: Formation of plagioclase-bearing peridotite and plagioclase-bearing wehrlite and gabbro suite through reactive crystallization: an experimental study, Contrib. Mineral. Petr., 167, 985, https://doi.org/10.1007/s00410-014-0985-7, 2014.

Schiano, P., Provost, A., Clocchiatti, R., and Faure, F.: Transcrystalline Melt Migration and Earth's Mantle, Science, 314, 970974, https://doi.org/10.1126/science.1132485, 2006.

Scholz, C.: Brittle fracture of rock, in: The Mechanics of Earthquakes and Faulting, Cambridge, Cambridge University Press, 1-42, https://doi.org/10.1007/978-3-7091-4109-0_5, 2019.

Sleep, N. H. and Warren, J. M.: Effect of latent heat of freezing on crustal generation at low spreading rates, Geochem. Geophy. Geosy., 15, 3161-3174, https://doi.org/10.1002/2014GC005423, 2014.

Sparks, D. W. and Parmentier, E. M.: Melt extraction from the mantle beneath spreading centers, Earth Planet. Sc. Lett., 105, 368377, https://doi.org/10.1016/0012-821X(91)90178-K, 1991.

Stevens, M. R., Bell., D. R., and Buseck, P. R.: Tubular symplectic inclusions in olivine from the Fukang pallasite, Meteoritics and Planetary Science, 45, 899-910, https://doi.org/10.1111/j.19455100.2010.01054.x, 2010.

Suhr, G., Hellebrand, E., Johnson, K., and Brunelli, D.: Stacked gabbro units and intervening mantle: a detailed look at a section of IODP Leg 305, Hole U1309D, Geochem. Geophy., Geosy., 9, Q10007, https://doi.org/10.1029/2008GC002012, 2008.

Sun, S. S. and McDonough, W. F.: Chemical and isotopic systematics of oceanic basalts: implications for mantle composition and processes, Geol. Soc. Spec. Publ., 42, 313-345, https://doi.org/10.1144/GSL.SP.1989.042.01.19, 1989.

Tommasi, A., Mainprice, D., Canova, G., and Chastel, Y.: Viscoplastic self-consistent and equilibrium-based modeling of olivine lattice preferred orientations: implications for the upper mantle seismic anisotropy, J. Geophys. Res., 105, 7893-7908, https://doi.org/10.1029/1999JB900411, 2000.

Wang, L., Blaha, S., Pintér, Z., Farla, R., Kawazoe, T., Miyajima, N., Michibayashi, K., and Katsura, T.: Temperature dependence of $[100](010)$ and $[001](010)$ dislocation mobility in natural olivine, Earth Planet. Sc. Lett., 441, 81-90, https://doi.org/10.1016/j.epsl.2016.02.029, 2016. 
Xiong, F., Yang, J., Dilek, Y., and Wang, C.: Nanoscale Diopside and Spinel Exsolution in Olivine from Dunite of the Tethyan Ophiolites, Southwestern Turkey: Implications for the Multi-Stage Process, J. Nanosci. Nanotechno., 17, 6587-6596, https://doi.org/10.1166/jnn.2017.14506, 2017.
Zhang, Y. and Cherniak, D. J.: Diffusion in minerals nd melts: Introduction, Rev. Mineral. Geochem., 72, 1-4, https://doi.org/10.2138/rmg.2010.72.1, 2010. 